\title{
Single coronary artery with double coronary courses: Tips and tricks
}

\author{
Murat Gula, Ozcan Ozeke ${ }^{b}$, Anil Ozen`, Fatih Mehmet Ucard, Serkan Cay ${ }^{b}$, \\ Dursun Aras ${ }^{b}$
}

\author{
${ }^{a}$ Department of Cardiology, Aksaray University, Aksaray, Turkey \\ ${ }^{b}$ Department of Cardiology, Health Sciences University, Turkiye Yuksek Ihtisas Training and Research Hospital, Ankara, Turkey \\ 'Department of Cardiovascular Surgery, Health Sciences University, Turkiye Yuksek Ihtisas Training and Research Hospital, \\ Ankara, Turkey

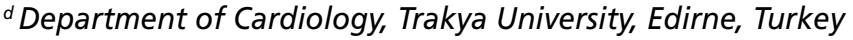

\section{ARTICLE INFO}

Article history:

Received: 5. 2. 2018

Received in revised form: 23. 7. 2018

Accepted: 24. 7. 2018

Available online: 8. 7. 2019

\section{Klíčová slova:}

Anomálie koronárních tepen

Jediná koronární tepna

Koronarografie

\section{SOUHRN}

Vrozené anomálie koronárních tepen nejsou časté a v převážné většině jsou diagnostikovány náhodně při koronarografickém vyšetření nebo při pitvě. Mezi nejvzácnější takové anomálie patří jediná koronární tepna. Pro určení její klinické významnosti je velmi důležité zjistit její průběh (interarteriální, intraseptální, prepulmonální nebo retroaortální). Pro pacienta je při objevení takové nečekané anomálie koronárních tepen nesmírně důležité stanovit správnou diagnózu; přitom je vždy na lékaři provádějícím angiografické vyšetření, aby přesně určil místo odstupu tepny a její průběh. Aby kardiologové dokázali anomálie koronárních tepen snadno identifikovat, musejí se seznámit se základními fakty.

(c) 2019, ČKS

\section{ABSTRACT}

Congenital coronary artery anomalies are uncommon and the vast majority is diagnosed incidentally during coronary angiogram or necropsy. A single coronary artery is one of the most rarely seen coronary artery anomalies. Determination of its course (inter-arterial, intra-septal, pre-pulmonic or retro-aortic) is very important regarding its clinical significance. Avoiding the misdiagnosis of an unsuspected anomalous coronary artery is critical to the patient and it is always the angiographer's responsibility to accurately define the origin and course of the vessel. Cardiologists should be aware of simple clues in order to easily identify

coronary anomalies.

Keywords:

Coronary angiography

Coronary anomaly

Single coronary artery

Congenital coronary artery anomalies are uncommon and the vast majority is diagnosed incidentally during coronary angiogram or necropsy. ${ }^{1,2}$ Single coronary artery (SCA) anomaly is rare, with incidence estimated at approximately $0.03-0.07 \%$, and approximately 20 possible variations of SCA have been described. ${ }^{3}$ Determination of its course (inter-arterial, intra-septal, pre-pulmonic or retro-aortic) is very important regarding its clinical significance. ${ }^{1,3,4}$ While the pre-pulmonic, intra-septal, and retro-aortic courses are considered to be benign, the inter-arterial course is often associated with an increased risk of sudden cardiac death. ${ }^{1,5}$ The SCA with double courses is a rare congenital anomaly of the coronary circulation. 6,7

A 65-year-old female patient referred to our hospital with the complaints of atypical chest pain but mild apical ischemia on nuclear stress testing. She had no significant medical history and physical examination was unremarkable. Electrocardiographic and echocardiographic findings were unrevealing. No origin of the coronary ostium arising from the left sinus Valsalva (LSV) could be imaged by the conventional coronary angiography (Video 1, http:// e-coretvasa.cz/suppl/2019-4-439-1.avi). A SCA originating from the right sinus of Valsalva (RSV) with a pre-pulmonic left anterior descending artery (LAD) and a retro-aortic left circumflex artery (LCX) was detected (Fig. 1, Video 2 http://e-coretvasa.cz/suppl/2019-4-439-2.avi and Video 3 http://e-coretvasa.cz/suppl/2019-4-439-3.avi).

Categorization of solitary SCA based on anatomy can be either classified as anomaly of the abnormal "origin" or as anomaly of abnormal "course" by the scheme propo- 


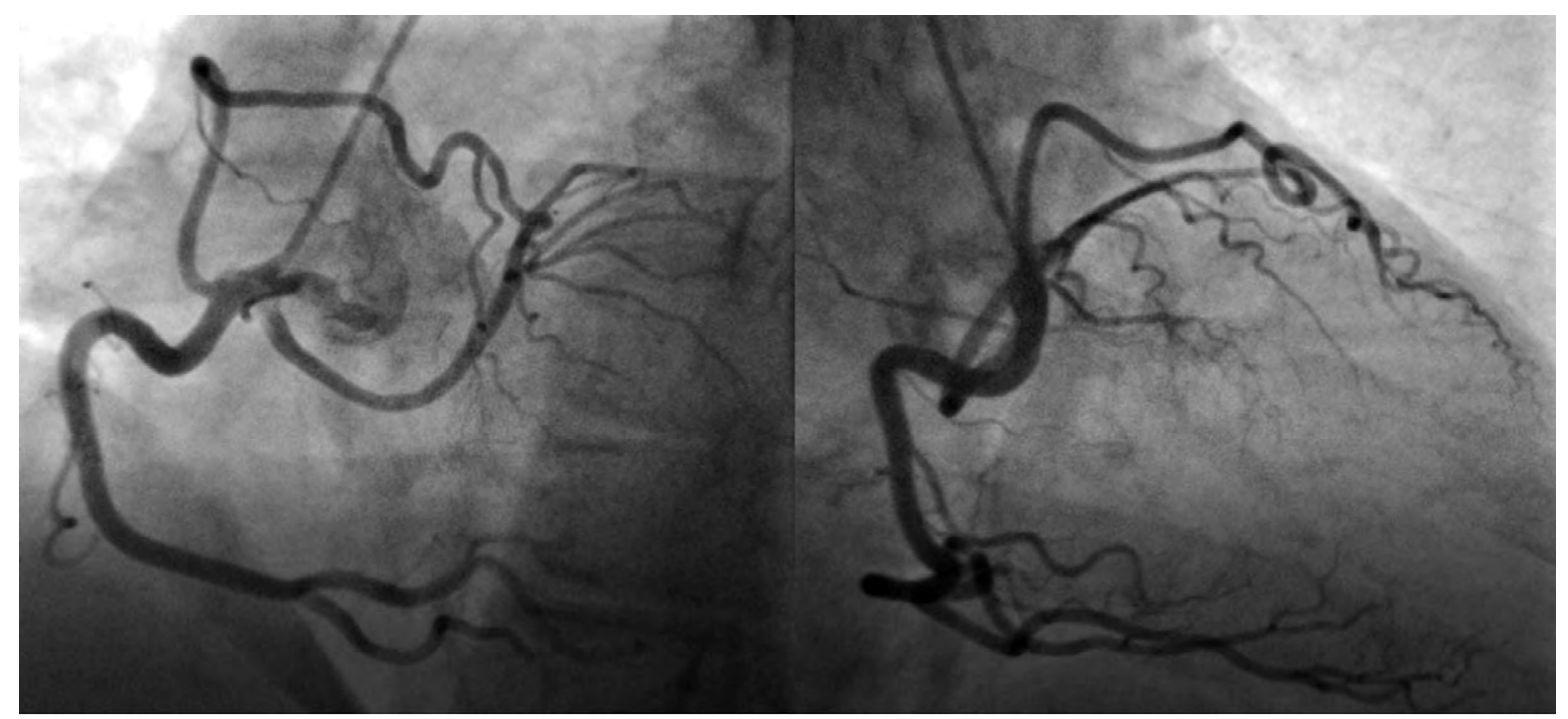

\begin{tabular}{|c|c|c|c|c|}
\hline \multicolumn{5}{|c|}{$\begin{array}{l}\text { The subtypes depending on the aberrant pathways to reach its proper vascular of } \\
\text { territory of the anomalous } L A D \text {. }\end{array}$} \\
\hline Type & Definition & Course & Curvature of long LAD & Clues \\
\hline A & $\begin{array}{l}\text { Antenor to the right ventricular } \\
\text { outllow tract }\end{array}$ & Prepulmonic (known as also precardiac) & Antero-cranial convex & $\begin{array}{l}\text { If the first branch arising from the long LAD is } \\
\text { the conal or infund bular branches }\end{array}$ \\
\hline B & $\begin{array}{l}\text { Between the aorta and } \\
\text { pulmonary trunk }\end{array}$ & Interarterial (known as also preaortic) & Postero-cranial convex & \\
\hline C & $\begin{array}{l}\text { Cristal, coursing through the crista } \\
\text { supraventricularis portion of the } \\
\text { intramuscular cource through the } \\
\text { upper portion of the } \\
\text { intraventricular septum }\end{array}$ & $\begin{array}{l}\text { Intraseptal (known as also subpulmonic } \\
\text { or septal) }\end{array}$ & Antero-caudal concave & $\begin{array}{l}\text { If the first branch arising from the long LAD } \\
\text { is the septal branch }\end{array}$ \\
\hline D & D-orsal or posterior to the aorta & Retroaortic (known as also retrocardiac) & Postero-caudal concave & Aortic root sign or Page's sign \\
\hline
\end{tabular}

Fig. 1 - Left anterior oblique (LAO) and right anterior oblique (RAO) angiogram shows single coronary artery with prepulmonic left anterior descending (LAD) artery and retroaortic circumflex artery. Ao - aorta.

sed by Lipton et al. ${ }^{8}$ According to Lipton's classification, SCA can be described using a three-character coded nomenclature in which the first alphabet represents ostial location, second number represents anatomical distribution, and third character represents the course of the transverse trunk. ${ }^{8}$ Depending on the location of the coronary ostium, the congenital anomaly is classified as " $R$ " type (originating from the RSV) and " $L$ " type (originating from the LSV). Based on the anatomy of the coronary arteries, it is classified as type I to III;

- In type I, there is a solitary dominant artery. The vessel follows the course of normal left or right coronary artery with a continuation into the missing artery's territory ( $R-I$ type as solitary dominant right coronary artery [RCA], and L-I type as solitary dominant left coronary artery).

- In type II, one coronary artery arising from the proximal portion of other normally located opposite coronary artery.

- In type III, the both LAD and LCX arise separately from the proximal part of a normal RCA. There is an absence of the left main coronary artery (LMCA). ${ }^{8}$
In current case, the LAD and LCX had separate origins from the proximal part of the normally located RCA (Video 2 http://e-coretvasa.cz/suppl/2019-4-439-2.avi). In general, this anomaly has no clinical significance unless atherosclerotic coronary artery disease superimposes. However, both LAD and LCX's courses are important. When the LAD and/or LCX originate from the proximal RCA or right sinus of Valsalva (RSV) (type II or type III), these anomalous vessels take 1 of 4 aberrant pathways to reach its proper vascular territory. These 4 pathways are as follows;

- type A (Anterior to the right ventricular outflow tract - "pre-pulmonic, conal or anterior free wall course with anterocranial convex curvature"),

- type B (Between the aorta and pulmonary trunk-"inter-arterial course with posterocranial convex curvature" "inter-arterial course"),

- type C (Cristal or Septal, coursing through the crista supraventricularis portion of the intramuscular course through the septum, along the floor of the right ventricular outflow tract, - "intra-septal course with anterocaudal concave curvature" "septal course"), and 
- type D (Dorsal or Posterior to the aorta- "retroaortic course" with posterocaudal concave curvature and the "aortic root" or Page's sign).

Of the 4 pathways of the anomalous course of coronary arteries, only inter-arterial variant is considered dangerous, and is associated with exertional angina, syncope, and sudden cardiac death. In current coronary anomaly was classified as type III SCA with a pre-pulmonic LAD and a retro-aortic LCX according to Lipton's scheme of classification.

Since even experienced angiographers have difficulty finding and delineating the true course of some anomalous vessels, a thorough method is required before making a definitive diagnosis. The course of the anomalous coronary can invasively be identified by angiography after insertion of a catheter into the pulmonary artery and another into the aorta, ${ }^{9}$ or by the "dot and eye method"4 in coronary angiography or noninvasively by computed tomography angiography..$^{10}$ In 1985 , Ishikawa et al. ${ }^{3}$ followed by Serota et al. ${ }^{4}$ in 1990 proposed a series of coronary angiographic criteria intended to define the relationship, along the initial course, between the anomalous vessel and the aorta and the pulmonary artery. These authors attempted to identify the different courses on the basis of the orientation of the "loop" formed by the anomalous coronary artery with the rest of the coronary tree ${ }^{3}$ or by applying the concept of the "dot" (visualization of the contrast column of the coronary artery anomaly which, because of the turn it makes, adopts the morphology of a dot). ${ }^{4}$ In a $30^{\circ}$ right anterior oblique (RAO) view, before turning to the apex at the midseptum, the LAD will pass left and upward (forming the upper half of the "eye" anterocranial convex loop-curvature) in an anterior free wall (pre-pulmonic or conal course) while it will pass left and downward (forming the lower half of the "eye" anterocaudal concave loop-curvature) in an intra-septal course. In case of an inter-arterial course the vessel will describe a cranial posterior loop before turning anteriorly towards the anterior interventricular sulcus in a RAO or LAO views (posterocranial convex curvature). The intra-septal course is also favored by the presence of phasic systolic compression of this segment similar to a myocardial bridge and proximal branching into septals. It is important to define the branching of an aberrant long LAD correctly as a septal artery (in always intra-septal course) or a conus artery (pre-pulmonicconal course) despite both may have anterocranial curvature-loop. In current case, the conus artery was an important clue for the pre-pulmonic LAD course (Video 2 http://e-coretvasa.cz/ suppl/2019-4-439-2.avi). Recognition of this variant and differentiation among the possible courses of the ectopic branch is essential for patient management. For all artery pathways that travel behind the aorta, the RAO projection during aortography or coronary angiography will visualize the artery on end and appear as a radio-opaque "dot" posterior to the aorta. Although the most important point for anomalous courses of coronary arteries is identifying the benign posterior or malignant anterior "dots" in the RAO view; this method was not useful in current case due to double separate courses of the SCA (Video 3).There was not another associated cardiac anomaly or coronary obstructive lesions. Cardiologists should be aware of simple clues in order to easily identify coronary anomalies.

\section{Conflict of interest}

There are no any potential conflicts of interest, including related consultancies, shareholdings, and funding grants.

\section{Appendix A. Supplementary data}

Supplementary material related to this article can be found, in the online version, at doi: https://doi.org/10.1016/j.crvasa.2018.07.007.

\section{References}

1. Villa AD, Sammut E, Nair A, et al. Coronary artery anomalies overview: The normal and the abnormal. World J Radiol 2016;8:537-555.

2. Yamanaka O, Hobbs RE. Coronary artery anomalies in 126,595 patients undergoing coronary arteriography. Cathet Cardiovasc Diagn 1990;21:28-40.

3. Ishikawa T, Brandt PW. Anomalous origin of the left main coronary artery from the right anterior aortic sinus: angiographic definition of anomalous course. Am J Cardiol 1985:55:770-776.

4. Serota H, Barth CW 3rd, Seuc CA, et al. Rapid identification of the course of anomalous coronary arteries in adults: the "dot and eye" method. Am J Cardiol 1990;65:891-898.

5. Kim SY, Seo JB, Do KH, et al. Coronary artery anomalies: classification and ECG-gated multi-detector row CT findings with angiographic correlation. Radiographics 2006;26:317-333 discussion 333-334.

6. Pasaoglu L, Toprak U, Nalbant E, Yagiz G. A rare coronary artery anomaly: origin of all three coronary arteries from the right sinus of valsalva. J Clin Imaging Sci 2015;5:25.

7. Shah S, Rajiah P. Single coronary artery with a pre-pulmonic dual left anterior descending artery and a retro-aortic left circumflex artery. Cardiol Young 2016;26:1241-1245.

8. Lipton MJ, Barry WH, Obrez I, et al. Isolated single coronary artery: diagnosis, angiographic classification, and clinical significance. Radiology 1979;130:39-47.

9. Turhan $\mathrm{H}$, Atak R, Erbay AR, et al. Double left anterior descending coronary artery arising from the left and right coronary arteries: a rare congenital coronary artery anomaly. Heart Vessels 2004;19:196-198.

10. Memisoglu E, Hobikoglu G, Tepe MS, et al. Congenital coronary anomalies in adults: comparison of anatomic course visualization by catheter angiography and electron beam CT. Catheter Cardiovasc Interv 2005;66:34-42. 